ks. Antoni Siemianowski

Uniwersytet im. Adama Mickiewicza w Poznaniu

DOI: $10.15290 /$ std.2018.04.05

\title{
WOKÓŁ DEFINICJI OSOBY. PROBLEMY Z DEFINICJĄ BOECJUSZA
}

\section{AROUND THE DEFINITION OF THE PERSON. PROBLEMS WITH THE DEFINITION OF BOETHIUS}

This article raises some reservations regarding Boethius' traditional definition of the person. Using the phenomenological method, I first try to point out the tedious and complicated way by which basic anthropological concepts such as the person and linguistic articulation are reached. When coming up with his definition of the person, Boethius subjected knowledge and the way in which man speaks about himself to order.

The main difficulty in man's ability to know and speak about himself is his own logos about himself, meaning his own ontological structure. The nature and essence of man is such that his being a person manifests itself in many ways in the creative dynamism of his personal life and in the unity of his ontic structure. One cannot employ methods and language that are used in life and science in order to come to know man as a person. This is why it is difficult to use scientific methods to make the person a subject of research and analysis. The phenomenological method, however, makes it possible to capture the many ways in which man manifests his personhood in the unified sense of the humanity within himself. This method also explains why it is difficult to confine the person to a strictly defined system of ideas.

While philosophers speak a lot about the person, it difficult to accurately and adequately express who and what the person is, and it is even more difficult to formulate a satisfactory theory of the person.

Key words: man, body, psyche, soul, spirit, human being, personal "I", subjectivity, self-consciousness. 
„...Człek tu przychodniem:

Nie znał, gdzie jest? Poglądał co? Nad nim, co? pod nim...

A potem rdzenia własnej samotności szukał,

A potem $w$ wyobraźnię... potem $w$ granit stukał;

Aż wyjrzał mu Bóg-fetysz z głuchego granitu,

Ten sam co był w sumieniu i gwiazdach u szczytu;

Ten sam...CO JEST"”

(C.K. Norwid, Rzecz o wolności słowa, 3,24 - 29)

Trendy naszych czasów są takie, że we wszystkie dziedziny usiłujemy wprowadzać definicyjne ustalenia i dokładne pomiary, wszystko usiłujemy określać, uściślać, mierzyć i ważyć; chodzi bowiem o to, aby w słowach i w mowie była jasność i jednoznaczność. Przyznać trzeba, że samo w sobie nie jest to sztuczne czy wygórowane żądanie, a tym bardziej niewłaściwe, czy niesłuszne; wręcz przeciwnie, właśnie prowadzi do dokładnego rozumienia języka i uściślenia całego procesu komunikacji. Pytanie tylko, czy wszystko, czego w sobie - w naszym samo doświadczeniu - dostrzegamy, da się ściśle i jednoznacznie określić, wymierzyć i wyważyć?

Otóż nasze samo doświadczenie faktu, że jesteśmy osobą, jest właśnie taką rzeczywistością, która nie daje się zamknąć w ścisłe jednoznaczne pojęcia i definicje. Stąd nic dziwnego, że - jak powiada Romano Guardini - osoba „wymyka się wszelkiemu treściowemu orzekaniu”.

Tymczasem w świecie osoba jest jako byt rzeczywistością najważniejszą. Jak zatem mówić o osobie? Jakie stawiać pytania? Bo często od postawionych pytań w dużym stopniu zależy trafność odpowiedzi. Na podstawie jakich źródeł poznania możemy w ogóle uzyskać prawomocne źródłowe poznanie osoby? Z jakich źródeł można czerpać adekwatną wiedzę o osobie? Z psychologii? Socjologii? Neurologii? Jaki charakter miałaby nasza wiedza o osobie czerpana $z$ tych nauk? Czy możliwe jest uzyskanie istotowe (ejdetyczne) poznanie osoby, a więc takie, które mogłoby stanowić swoiste apriori dla wszelkich wypowiedzi o osobie? Czy może skazani jesteśmy tylko na domniemania i interpretacje? Na konstrukcje pojęciowe? Przy współczesnym kryzysie wiedzy filozoficznej o człowieku i przy ogólnym kryzysie współczesnego myślenia filozoficznego osoba zdaje się zupełnie wymykać poznaniu. Teoretyczne wypowiedzi o osobie padają dziś ofiarą pojęciowego chaosu, który trudno przezwyciężyć.

Zob. tom pism Koniec czasów nowożytnych - świat i osoba - wolność, łaska, los, Kraków 1969. 
$* * *$

Spróbujmy jednak poczynić pewne kroki, aby - w fenomenologicznym rozumieniu - przyjrzeć się rzeczy samej, tzn. osobie ludzkiej - i próbować wypatrzeć w różnych przejawach pierwotnego faktu naszego bycia osobą jej własny ejdos, czyli jej „właściwy wygląd”.

Na fakt naszego bycia osobą spójrzmy najpierw od strony naszej cielesności. Jako osoba jestem rzeczywistością niewidzialną, ukrytą wewnątrz mnie samego, ale całe moje bycie osobą jest związane $z$ ciałem. W moim życiu osobowym solidaryzuję się z tym wszystkim, co jest właśnie widzialną cielesną stroną mego bytu, czyli z moim ciałem. Ciało jest pierwotnym źródłowym miejscem mojej obecności w świecie. Jestem w świecie obecny i dostępny dla drugich tylko w moim ciele i poprzez moje ciało. Od poczęcia do zejścia z tego świata jako osoba żyję w ścisłej łączności z moim ciałem, w ciele i dzięki ciału - rzec nawet można - jako osoba jestem $w$ ciele i z ciała. Bez ciała i poza ciałem nie doświadczam mojego ludzkiego życia osobowego. Jako osoba jestem zatem ucieleśniony, a przez to we wzajemnym obcowaniu widzialny, dotykalny, żywy, rzeczywisty. I trzeba dodać, że owo ścisłe powiązanie mego osobowego ja z ciałem jest pierwotna dana zarówno w życiu potocznym, jak i dla mnie samego, a więc dla mojej samowiedzy. Wiem to bezpośrednio z całą pewnością, że od samego początku jestem obecny w ciele, przez ciało odczuwam drugich i świat wokół siebie, poprzez ciało komunikuję się z drugimi, jako ciało jestem widzialny dla drugich. Zatem całe moje uczestnictwo w ludzkim życiu osobowym jest cielesne.

Ja jako osoba uobecniam się w ciele, identyfikuję się z moim ciałem, dlatego mogę powiedzieć: moje ciało to ja. Ale czy mógłbym powiedzieć, że moje bycie osobą to bycie tylko ciałem i nic więcej? Czy moje bycie osobą da się wyjaśnić przez odwołanie się do ciała i procesów w nim zachodzących? Prawda, bez ciała nie ma mnie w świecie jako osoby, ale moje ludzkie życie osobowe nie wyczerpuje się jednak w ciele i nie kończy się na ciele. Zatem mojego bycia osobą nie mogę ograniczyć do bycia ciałem, a gdybym to uczynił, to przestałbym być dla drugich kimś, a stałbym się czymś. Tak więc, gdy wnikliwiej zastanawiam się nad faktem mojego bycia osobą, tym bardziej gubię się w myślach o sobie, nie umiem sobie jasno i wyraźnie odpowiedzieć na to bardzo proste pytanie, co konstytunje moje bycie osoba. Wiem jednak z całą pewnością źródłowego poznania, że w świecie jestem osobą we wspólnocie z drugimi; nie w stadzie, ale we wspólnocie. Ci, którzy mówią, że osoba jest czymś pochodnym - tworem refleksji, języka lub jakiegoś procesu uczłowieczania się pierwotnego stada zwierzęcego - nie dostrzegają, że to właśnie refleksja skłonna do pochopnych uogólnień lub nieuzasadnionych interpretacji przesłania mi mój „prawdziwy 
wygląd" - moje ejdos - jako osoby. W słowach i pojęciach jednak łatwo uwikłać się w błędne poglądy i wymyślone teorie.

\section{$* * *$}

Dotąd nie padło jeszcze słowo duch. Ale przecież o osobie trudno coś trafnego powiedzieć nie odwołując się właśnie do ducha. Bo czyż jako osoba tak naprawdę nie odnajduję się dopiero w niewidzialnej zmysłowo sferze ducha? W sferze myśli i dążeń pozacielesnych, rozciągających się na cały świat widzialny i niewidzialny? Jest to więc jeszcze inny wymiar bycia osobą, inny, ale równie rzeczywisty jak moje ucieleśnione bycie osobą. Chodzi tu o wielorakie wykraczanie osoby poza samą siebie, a nawet poza świat, w którym istnieję jako osoba i z którym związana jest moja osobowa egzystencja. Osoba - rzeczywistość ukryta $w$-sobie-dla-siebie - zarazem zdolna do uczestnictwa w życiu drugich osób, rzeczywistość uobecniająca się jako ciało w konkretnym organizmie w świecie materialnym i poprzez związki ze światem dochodząca pełni własnego bycia sobą - nie wyczerpuje sensu swej egzystencji w świecie i dla świata. Można zatem powiedzieć, że osoba nie jest powołana dla świata. Świat dla osoby jest za mały. Ale jeśli osoba nie jest dla świata, to tym bardziej sensowne jest pytanie, dla kogo? Jakie jest jej własne przeznaczenie? Czy osoba istnieje dla samej siebie? Czy dla innych wartości? Ale jeśli dla innych, to od razu pytanie dla jakich? Będąc w świecie bytem materialno-cielesno-duchowym, osoba żyje duchem i dopiero w sferze ducha osiąga pełnię swego przeznaczenia. Jest to jeszcze inny powód, dla którego trudno opisać osobę, określić ją w prostych formułach definicyjnych zamykając sens jej bytu w obiegowych kategoriach filozoficznych, zwłaszcza w kategoriach substancji i przypadłości czy za pomocą związków materialno-cielesnych odnoszących się do świata natury. Zatem nic dziwnego, że trudno jasno i ściśle opisać i wyjaśnić strukturę i egzystencję osoby jako bytu w świecie. Słusznie zatem Romano Guardini mówi także o „szczególnej nieuchwytności pojęcia” osoby.

Mówiąc o osobie, musimy wyjšć od doświadczenia bytu, którym sami jesteśmy. Tak Edyta Stein. Nie ma innej pewniejszej drogi do możliwie adekwatnego poznania osoby.

Wpierw jednak spójrzmy na historię kształtowania się językowych określeń osoby. Europejskie odkrywanie osoby - sensu jej bytu, jej miejsca w świecie, jej godności i znaczenia oraz jej praw - przebiegało różnymi i jakże często krętymi drogami. Trudno je wszystkie prześledzić. Z tej racji epistemologiczna 
i ontologiczna problematyka osoby jest złożona i powikłana, jakby zapętlona we własną historię poszukiwań sensu bycia człowiekiem i osobą.

Człowiek w ogromnym trudzie odkrywał nie tylko swoją osobową strukturę - sens swego bytu jako osoby - ale także w żmudnym trudzie odkrywał swoją cielesną strukturę ${ }^{2}$. Widząc bowiem jasno i wyraźnie, że jest ciatem i to ciałem bardzo podobnym do ciał zwierzęcych, nie poprzestawał jednak na tym stwierdzeniu. Postrzegając członki własnego ciała, widział, że bez rąk czy nóg może żyć, ale bez głowy, serca, krwi czy oddechu nie. Dlaczego? Gdy zatem - jak mówi C.K. Norwid - „rdzenia własnej samotności szukał” - stopniowo odkrywał, że będąc ciałem organicznym, w swej cielesnej strukturze ma coś innego, coś więcej - a więc jakąś Boską cząstkę. Tą Boską cząstką był ukryty w tym, co stosunkowo wcześnie nazwano dusza - jego logos. Stąd zdumienie Heraklita: „Granic duszy nie znajdziesz, choćbyś przeszedł wszystkie drogi. Tak głęboki jest jej logos”3. Źródłowe samopoznanie wymagało jednak czasu i żmudnych dociekań nad tym, co w bycie człowieka składa się na ów logos człowieczeństwa, i co jest ważne w jego byciu człowiekiem: głowa, ręce, nerki, serce i oddech czy też to, co właśnie w nim samym Boskie - logos. Jednak według ogólnego przeświadczenia Greków ów logos był tym decydującym czynnikiem, bo siedliskiem myśli, słów, źródłem mowy ${ }^{4}$. Wszystko to są przejawy bycia człowiekiem, których nie ma w świecie zwierzęcym. W ten sposób Grecy stopniowo odkrywali w człowieku odrębną sferę ducha.

W procesie mowy człowiek o sobie samym mówił prawomocnie ja, a wskazując na drugiego mówił ty, w gromadzie zaś mówił my. Tak dzieje się w sferze ducha. Świat zwierzęcy nie zna czegoś takiego jak ja, ty, my. Ale i te fundamentalne różnice i więzi także długo wymykały się jasnemu zrozumieniu. Jednak ze względu na logos w sobie samym - własnego bytu w całości - widział siebie kimś innym, bo wyższym ponad inne jestestwa w świecie. Dlatego też ani siebie, ani drugiego nie traktował jak rzeczy; nie mówił, że drugi to coś. W procesie komunikacji drugi zawsze był to ktoś.

2 Zwraca na to uwagę Bruno Snell w swej książce Odkrycie ducha. Studia o greckich korzeniach europejskiego myślenia, tłum. A. Onysymow, Warszawa 2009.

3 Filozofia starożytna Grecji i Rzymu, s. 82.

4 Bruno Snell, analizując słownictwo Homera i wczesnych poetów greckich, pokazuje, jak żmudnie rodziły się takie słowa, jak ciało, organizm, serce, umysł, dusza, duch (zob. cytowane wyżej Odkrycie ducha. Studia o greckich korzeniach europejskiego myślenia, tłum. A. Onysymow, Warszawa 2009, s. 17 in.). 
$* * *$

Przy tej okazji warto zwrócić uwagę na inne jeszcze intuicje poznawcze, jakie wiążą się w kulturze europejskiej z kształtowaniem się treści słowa oso$b a$, a potem także na racje, jakie przemawiały za tym, aby brać pod uwagę te a nie inne momenty treściowe. Otóż greckie słowo prosopon w starożytności pogańskiej w mowie potocznej oznaczało zwyczajną maskę aktora; wygląd zewnętrzny człowieka, rolę, czy postać występującą w teatrze lub w sztuce, a w języku prawniczym rolę oskarżyciela, obrońcy lub sędziego; natomiast w gramatyce oznaczało to samo, co i dziś: jedną z form czasownika użytego jako orzeczenie. Słowo o tak chwiejnym - a raczej płynnym znaczeniu - weszło do filozofii bardzo późno i utrwaliło swoją obecność zupełnie okrężnymi drogami, bo najpierw przez przekład Starego Testamentu z języka hebrajskiego na język grecki, zwany Septuaginta. Otóż w języku greckim słowem prosopon oddano hebrajskie paneh. I tu mamy trop nowego znaczenia, które zrosło się ze słowem osoba. Otóż hebrajskie paneh oznacza m.in. twarz, oblicze. Podstawą do takiego rozumieniu była ta okoliczność, że gdy Izraelita słuchał Boga i stawał przed Jego obliczem, słuchał Go jako ktoś, kto występuje osobiście i bezpośrednio mówi do Boga jak do człowieka. W ten sposób w Septuagincie greckie słowo prosospon zyskało nowe znaczenie: wskazywało na żywą obecność transcendentnego Boga, na oblicze tego, kto - choć sam w sobie niewidzialny - jest osobiście obecny i mówi do człowieka. Stąd już niedaleka droga, aby greckie słowo prosopon-maska odnieść także do żywego człowieka.

Jednak w filozofii słowo prosopon zyskało nowe i donioślejsze znaczenie bardzo późno, bo dopiero w czasach chrześcijańskich, gdy zostało zastosowane w dociekaniach nad człowieczeństwem Chrystusa. Ale to znowu dokonywało się drogą okrężną, bo za pośrednictwem sporów chrystologicznych i trynitarnych - jeśli tak można powiedzieć - o strukturę ontyczną Chrystusa, a wśród sporów trynitarnych o pozycję osoby w Trójcy Świętej. W kontekście tych sporów greckie słowo prosopon - a łacińskie persona - stawało się terminem, który nabierał już wyraźnie znaczenia antropologicznego i zarazem ontologicznego, ale wcale nie wyzbyło się wieloznaczności. Prosopon najpierw oznaczało jednostkowy byt jako podmiot przypadłości, a w rozumieniu filozoficznym substancję. W języku greckim prosopon współwystępowało z innym terminem, a mianowicie hypostasis. Termin ten oznaczał coś więcej, bo naturę i istotę jednostkowego bytu, a więc czegoś, co określano mianem substancji. W sporach chrystologicznych i trynitarnych z trudem jednak dochodziło do możliwie jasnego rozumienia terminu osoba, zwłaszcza że spory te - jak później trafnie zauważył Boecjusz - często wzniecali ludzie, którzy „niedostatki wiedzy usiłują przesłonić chmurą uporu i bezczelności, skoro częstokroć nie tylko nie wiedzą 
tego, o czym mówią, ale nawet $\mathrm{w}$ tego rodzaju sporach nie rozumieją, co sami mówią" . Była to niezwykle trafna diagnoza sytuacji czy - jeśli tak można powiedzieć - stanu kulturowego tamtych czasów.

\section{Rola św. Augustyna i Boecjusza w rozumieniu osoby}

Na Zachodzie geniusz literacki i teologiczny św. Augustyna rozwikłał wiele trudności i wytyczył na długie wieki - a właściwie aż do dziś - drogi rozumienia prawd wiary, zwłaszcza tajemnicy Trójcy Świętej. Święty Augustyn mówił wprawdzie o osobach Bożych Ojca, Syna i Ducha Świętego oraz o różnicy w ich wzajemnych odniesieniach. Ten kontekst religijny pozwolił mu zarysować ogólne rozumienie słowa osoba. Jego ustalenia były niezwykle precyzyjne tam, gdzie było to możliwe. Ale on sam zdawał sobie sprawę z niejasności słów i z ich możliwego wielorakiego rozumienia na Wschodzie i na Zachodzie, zwłaszcza terminów ousia i hipostasis - substancja i osoba.

„Wiara szuka, rozum odkrywa” - pisał. Ta lapidarna formuła doskonale wyraża kierunek jego poszukiwań. Z całego serca pragnął „myślą widzieć to, w co uwierzył”. A to znaczyło u niego: „widzieć Boga i mocno się w Niego wpatrywać oczami ducha" i szukać. Święty Augustyn uwierzył w Boga, uwierzył także w Jezusa Chrystusa jako Syna Bożego i w Jego zbawcze dzieło. Wszystko to chciał zrozumieć i połączyć w jedną spójną całość. Obrał więc taką drogę: aby zrozumieć Boga i Jego tajemnice, najpierw dokładnie analizował różne wypowiedzi Pisma Świętego, a następnie naturę człowieka, a zwłaszcza życie własnej duszy. Zagłębiał się $\mathrm{w}$ istotę myślenia i poznania, w istotę pamięci i słowa, w istotę woli i miłości. We własnej duszy zatem dostrzegał ślady Boga, swego Stwórcy i Pana, a więc jedność Bożej natury ze względu na tę samą naturę czy substancję, a różnice Bożych osób ze względu na ich wzajemną wspólnotę.

Pismo Święte mówi o Ojcu, Synu i Duchu Świętym. Czyż to nie wskazuje wyraźnie na obecność trzech osób? Jeśli wymieniamy trzy osoby, to wymieniamy je tylko ze względu na różnice, jakie zachodzą w ich wzajemnym odnoszeniu się do siebie, czyli w relacjach. I tak w odnoszeniu się Ojca do Syna, a Syna do Ojca mamy relację ojcostwa i synostwa, a w odniesieniu Ojca i Syna do Ducha Świętego, a Ducha Świętego do Ojca i Syna mamy relację daru. Ale między Ojcem a Synem zachodzi również „jakaś niewysłowiona wspólnota”, która istnieje także pomiędzy Ojcem i Synem a Duchem Świętym. Ze względu na tę „niewysłowioną wspólnotę” osób mówimy o Bogu, że jest jeden i że jest

\footnotetext{
5 Opociechach filozofii ksiag pięcioro oraz traktaty teologiczne, thum. T. Jachimowski, Poznań 1927, s. 224.

6 O Trójcy Świętej, (VIII, 4,6), s. 264.
} 
Początkiem wszystkiego, cokolwiek od Niego pochodzi. Natomiast ze względu na różnice we wzajemnych relacjach wyodrębniamy osoby Boże: Ojca, Syna i Ducha Świętego. Biorąc pod uwagę różne wypowiedzi Pisma Świętego o Ojcu, o Synu i o Duchu Świętym oraz o ich wzajemnej wspólnocie, św. Augustyn próbował ustalić pojęcie osoby w Bogu jako wyjątkowej samoistnej relacji. Jego spekulacja była taka: w Bogu osoby są samoistne, albowiem istnieją w tej samej Bożej naturze czy substancji, a w Bogu nie ma nic przypadłościowego. Jeśli Bóg Ojciec rodzi Syna, to Syn wiecznie jest Synem; jeśli Ojciec i Syn posyłają jako dar ich wzajemnej miłości Ducha Świętego, to Duch wiecznie jest Darem. Święty Augustyn mówi: „...każdy z nich jest tym, co się o Nim mówi, nie sam w sobie, ale w odniesieniu do drugiego, i nazywa się tak ze względu na stosunek do tego drugiego. Nie ma tu jednak przypadłości, gdyż to, co się nazywa Ojcem, i to, co się nazywa Synem, jest wieczne i niezmienne. Dlatego -choć to coś innego być Ojcem i być Synem - substancja jednak nie jest różna”?

Skoro Pismo Święte mówi, że Ojciec rodzi Syna oraz że Ojciec i Syn posyłają Ducha Świętego, to czyż to nie oznacza właśnie wzajemnego odnoszenia się trzech Osób Bożych do siebie? Zatem św. Augustyn słowo relacja uznał za jak najbardziej stosowne dla wskazania na różne osoby w Bogu. I tak samo za stosowne uznał używanie słów takich, jak istota, natura, substancja.

Nasuwa się teraz pytanie, czy wywody św. Augustyna można by interpretować w ten sposób, że odnoszenie się, czyli relację uważał on za istotę lub naturę osoby w ogóle? Trudno cokolwiek przesądzać, albowiem słów istota i natura św. Augustyn używał w innym znaczeniu. Ale na pewno zarysował ogólne pojęcie osoby jako samoistnej czy substancjalnej relacji w Bogu; to jednak nie oznaczało jeszcze definicji pojęcia osoby w ogóle. Święty Augustyn definiowania raczej unikał, był bowiem świadomy, że Pismo Święte niczego w tej dziedzinie nie rozstrzyga. Co prawda występuje w nim słowo prosopon, ale nie ma pojęcia osoby, milczy także o pojęciach substancji, natury, istoty czy relacji. Podkreślał jednak, że z jednej strony, braki naszej mowy, a z drugiej, konieczność dyskusji nad błędami heretyków zmuszają nas do używania słów o różnych znaczeniach, z których pomocą usiłujemy przekazać umysłom ludzi to, co sami w tajemnej głębi duszy pojmujemy o Panu Bogu. Lecz nade wszystko św. Augustyn był świadomy granic ludzkiego poznania w dziedzinie wiary. Wiedział, że nie wszystko da się ściśle określić i wyjaśnić. Warto przytoczyć dłuższy tekst, który charakteryzuje jego sposób myślenia w poszukiwaniu zrozumienia treści wiary w Trójcę Świętą:

Mówię „istota”, po grecku „ousia”, my jednak częściej posługujemy się terminem „substancja”. Grecy mówią również: „hipostaza”. Nie wiem jednak dokładnie, na

Ibidem, (V,5,6), s. 212. 
czym polega różnica pomiędzy „ousia” a „hypostasis”... Zakorzeniony u nas sposób mówienia doprowadził do tego, że mówiąc „istota”, rozumiemy to samo, co oznacza „substancja”. Dlatego nie ośmielamy się powiedzieć: jedna istota, trzy substancje, ale: jedna istota albo substancja, trzy osoby. Tak mówią liczni łacinnicy, poważni i wiarogodni, nie znajdując bardziej odpowiedniego sposobu wyrażania słowami tego, co pojęli bez słów. W rzeczy samej, Ojciec nie jest Synem, ani Syn Ojcem, a Duch Święty, którego nazywa się również Darem, nie jest Ojcem, ani Synem, a więc rozumie się, że są Trzej. (...) Gdy jednak pytamy: Co za Trzej? wówczas język ludzki zmaga się z wielkimi trudnościami. Odpowiada się wprawdzie: „Trzy Osoby”, ale mówi się tak nie tyle po to, żeby je wyrazić, co raczej dlatego, żeby nie pozostać nic nie powiedziawszy ${ }^{8}$.

Chciałoby się myśl św. Augustyna rozwinąć: O Bogu musimy mówić naszym ludzkim językiem, ale musimy zarazem pamiętać, że Boga nie poznajemy bezpośrednio w jasnym widzeniu.

Kończąc dzieło O Trójcy Świętej, tak w modlitwie rekapitulował swoje myśli:

Panie, Boże nasz, wierzymy w Ciebie, Ojca, Syna i Ducha Świętego. Bo nie mówiłaby Prawda: „Idąc tedy, nauczajcie wszystkie narody, chrzcząc je w imię Ojca i Syna, i Ducha Świętego", gdybyś Trójcą nie był. I nie kazałbyś nas chrzcić w imię Tego, który by nie był Panem i Bogiem. Głos Boży nie mówiłby: „Słuchaj Izraelu! Pan, Bóg nasz, Pan jeden jest”, gdybyś nie był Trójcą, a jednocześnie jedynym Panem i Bogiem.

Gdybyś Ty, Boże Ojcze, nie różnił się od Syna, to znaczy Słowa twego i Jezusa Chrystusa, ani od Waszego Daru, Ducha Świętego, nie czytalibyśmy w Piśmie św. prawdy: „Posłał Bóg Syna swego”, ani Ty, Jednorodzony, nie mówiłbyś o Duchu Świętym: „Którego Ojciec pośle w imię moje” i „Którego ja wam poślę od Ojca”. Trzymając się tej zasady wiary, kierowałem całym swoim wysiłkiem; nie szczędziłem własnych sił i liczyłem na Twoją pomoc, aby szukać Ciebie. Pragnąłem widzieć siłami umysłu to, w co wierzyłem. Wiele dociekałem, wiele pracowałem ${ }^{9}$.

W ten sposób wiążąc w jedną spójną całość wysiłek swojego umysłu z wiarą, św. Augustyn zarysował rozumienie osoby jako samoistnej relacji w Bogu. Dało to początek tzw. relacyjnemu ujęciu osoby ludzkiej. Wcale to jednak nie znaczyło, że św. Augustyn sprowadził pojęcie osoby do pojęcia relacji? Trudno św. Augustyna posądzać o takie uproszczenie, niejedni jednak mogli je tak odczytywać.

$* * *$

W historycznym procesie doprecyzowania pojęcia osoby ważną rolę odegrał Boecjusz, filozof żyjący sto lat po św. Augustynie (480-524). W historii filozofii jest znany przede wszystkim jako autor dzieła $\bigcirc$ pocieszeniu filozofii (w którym

Ibidem, (V,8,10), s. 216-217.

Ibidem, (XV, 18, 51), 458. 
n.b. nie ma ani słowa o osobie). Człowiek niezwykle wykształcony w filozofii, znał bardzo dobrze pisma logiczne Arystotelesa, ale doskonale też był zorientowany w teologii. Śmiało można o nim powiedzieć - wielki erudyta. Jego dewizą było: „Połącz, jeśli możesz, wiarę i rozum”. Jest jego wielką zasługą, że swoimi pismami przyczynił się do załagodzenia sporów chrystologicznych. Słynną definicję osoby zamieścił w dziełku $\mathrm{O}$ osobie $i$ dwóch naturach przeciwko Eutychesowi $i$ Nestoriuszowi ${ }^{10}$.

Dociekania Boecjusza - a to trzeba mocno podkreślić - miały wyraźnie charakter logiczny, a nie ontologiczny; nie analizował on bytu osoby, lecz skupił się jedynie na analizie sposobów orzekania pojęć o podmiocie zdania. Zatrzymał się więc na płaszczyźnie języka. Wyszedł od analizy wypowiedzi o Chrystusie, zawartych w teologicznych formułach orzekających, że Jezus jest Synem Bożym i człowiekiem. W V wieku pojawiły się różne interpretacje osoby Chrystusa, których Kościół nie akceptował, uznając je za heretyckie. I tak Nestoriuszowi przypisywano opinię, że głosi, iż w Jezusie są dwie osoby. Natomiast Eutyches głosił, że w Jezusie obie natury, Boska i ludzka, tak się zlewają ze sobą, iż tworzą jedną nową naturę. Kluczowe w tych wypowiedziach były dwa pojęcia: osoby i natury. Jak rozumieć te pojęcia, ażeby uniknąć herezji? Boecjusz te pojęcia poddał gruntownej analizie.

Postępował niemal jak współczesny filozof analityk. Na początku rozważył różne sposoby używania w zdaniach słów natura i osoba. I tak przyjął, że natura „to różnica gatunkowa, ukształcająca każdą rzecz”. Takie pojęcie natury orzekamy przede wszystkim o 1. samych ciałach; o 2. samych substancjach cielesnych lub niecielesnych; 3. o jakimkolwiek istnieniu. W tym ostatnim przypadku ,naturą rzeczy jest to, że już przez samo swoje istnienie mogą być one w jakikolwiek sposób pojęte" ${ }^{11}$. Jest to najogólniejsze rozumienie słowa natura. Cokolwiek istnieje i jest poznawalne, ma określoną naturę. W ściślejszym rozumieniu słowo natura wypowiadamy o tym, co może działać lub przyjmować działanie, czyli o substancjach cielesnych lub niecielesnych. Ale słowa natura używamy także wtedy, gdy wskazujemy na zasadę czegoś, np. na zasadę tzw. ruchu naturalnego, który odróżniamy od ruchu przypadkowego. Natomiast słowo osoba wypowiadamy o czymś, co jest konkretną żywą substancją i to substancja rozumna; bo o koniach czy drzewach nie mówimy, że są osobami. Słowa osoba nie wypowiadamy także o substancjach powszechnych czy o rzeczach. W ścisłym jednak znaczeniu słowo osoba wypowiadamy jedynie o człowieku, o Bogu i o aniołach, a to znaczy, że wyłącznie o substancjach rozumnych.

$10 \quad$ Ibidem, s. 224-249.

$11 \quad$ Ibidem, s. 227. 
Skoro zatem słowo osoba wypowiadamy jedynie o substancjach rozumnych, to zakładamy jednocześnie, że każda z nich jest zdeterminowana określoną naturą „ukształcającą każdą rzecz”. Ustaliwszy to, Boecjusz sformułował swoją słynną definicję osoby: „Osoba jest poszczególną substancją natury rozumnej persona est naturae rationabilis individua substantia"12. W tym wypadku możemy już mówić o wyraźnej definicji, ale jedynie pojęcia osoby, nie zaś natury osoby jako konkretnego monadycznego bytu. Ale na podstawie czego tak orzekamy? Odpowiedź jest bardzo krótka: na podstawie logicznej analizy używania słowa osoba w różnych zdaniach, a nie na podstawie źródłowego doświadczenia bytu osoby, czyli wglądu w jej istotę jako określonego bytu. Istota osoby, zwłaszcza osoby ludzkiej, pozostała nadal w cieniu, zredukowana co najwyżej do rozumności.

Formułując taką definicję pojęcia osoby - powiedzmy językowa - Boecjusz zdawał sobie doskonale sprawę z tego, że Grecy obok słowa prosopon - osoba używają w tym samym znaczeniu także słów hipostaza, i subsystencja. Zawsze jednak te słowa orzekano o jednostce ludzkiej, czyli o substancji rozumnej, a nie o jakiejkolwiek substancji. Boecjusz z naciskiem podkreśla, że osobą może być jedynie taki byt, który 1 . istnieje sam w sobie; 2 . jest konkretną całością bytową (indywiduum); 3. jest solidnie w sobie ukształtowany przez swoją naturę, a nie przez jakąś przypadłość; i 4. natura ta jest rozumna (natura intellectualis). Natomiast ustalenie różnicy między naturą a osobą Boecjusz pozostawia „kościelnemu sposobowi mówienia”, czyli chrześcijańskiej wykładni prawd wiary. On sam, posługując się analizą logiczną pojęcia natury, starał się dowieść, że absurdalny jest pogląd Eutychesa o zlaniu się w Chrystusie dwóch natur, Boskiej i ludzkiej w jedno.

\section{Dziedzictwo historyczne Boecjusza}

Definicja osoby Boecjusza zrobiła wielką - jeśli tak można powiedzieć - karierę w dziejach chrześcijaństwa. Na Zachodzie została powszechnie przyjęta w teologii, a później także w filozofii. Ale to oczywiście nie znaczy, że pojęcie osoby należy wyłącznie do sfery religijnej i że wypracowane zostało tylko na użytek teologii. Jedno trzeba tu podkreślić: Boecjusz swej definicji nie formułował na podstawie źródłowego poznania istoty osoby, lecz tylko na podstawie analizy znaczenia używanych pojęć (dzisiaj powiedzielibyśmy, że tworzył teoretyczny konstrukt). Ale w chrześcijańskim nauczaniu przez wieki ta definicja - mówiąc dzisiejszym językiem - uchodziła za definicję osoby adekwatną i merytorycznie trafną, bo określającą istotę osoby. I jako taka była w większości akceptowana.

W tradycyjnej filozofii - i w teologii - wychodzenie od definicji uchodziło za krok jak najbardziej właściwy. Działał tu zresztą autorytet Arystotelesa.

12 Ibidem, s. 229. 
Przyjmowano za nim jako coś oczywistego, że definicja jest wykładnikiem trafnego rozpoznania natury przedmiotu, może zatem dostarczać najogólniejszych danych do dalszych wywodów. Jednak w wypadku osoby taki krok wydaje się niewłaściwy. Dlaczego? Widzę dwa powody - pierwszy - zbudowanie poprawnej definicji osoby jest zadaniem niemożliwym do wykonania i drugi - jest zabiegiem zbędnym. Osoba nie jest ani gatunkiem, ani rodzajem, ani różnicą gatunkową. Osoba jest wyłącznie czymś niepowtarzalnym. Jest to jedna jedyna - monada egotyczna w petni uksztaltowana. Na tę sytuację zwrócił już uwagę Ryszard od św. Wiktora. Krytykując definicję Boecjusza; uważał, że osoba to coś niepowtarzalnego, coś, co przysługuje tylko jednemu [podmiotowi]: proprietas, quae non convenit nisi uni soli ${ }^{13}$. Boecjusz wskazał jedynie na konieczne warunki bycia osoba, jakimi są warunki orzekania pojęcia osoby o podmiocie zdania. Według niego pojęcie osoby można wypowiadać jedynie o czymś takim, co jest jednostkowa substancja, tzn. całością bytową wyraźnie odgraniczoną od innych substancji i w sobie zamkniętą; całością samoistną, czyli taką, której przysługuje bycie w sobie, a nie w czymś innym. Ponadto substancja, o której wypowiadamy pojęcie osoby, musi mieć określoną naturę. Według Boecjusza musi to być natura rozumna. Nie jest to więc żadną miarą kawałek czegoś określonego - drewna lub złota, ani nawet coś żywego - roślina czy koń. Osobą może być tylko taka substancja, jaką jest człowiek - anioł lub Bóg - a więc substancja obdarzona zdolnością myślenia i rozumowania. Czy to znaczyłoby, że Boecjusz wziął pod uwagę samoświadomość człowieka jak św. Augustyn? Sądzę, że nie; Boecjusz na pewno nie myślał o samoświadomości. Chodziło mu wyłącznie o podmiot rozumowego poznania, a taki podmiot może być jedynie w duszy. Orzekając o takim podmiocie pojęcie osoby, traktujemy to pojęcie jako wskazujące na różnicę gatunkową, wyróżniającą i tym samym określającą daną jednostkową substancję. Ale pojęcie to można orzekać o każdej innej jednostkowej rozumnej naturze.

Z definicji osoby jako rozumnej substancji czy rozumnej natury Boecjuszowi umknęło jednak coś bardzo ważnego: sama osoba jako ten, kto osobno jest sobą, $k$ to istnieje sam jeden jedyny - w-sobie-dla-siebie, niepowtarzalny, nieudzielalny, czyli jako żywe monadyczne Ja, którego - jako jedynego - nie można już orzekać o nikim innym. Dlatego to w przypadku osoby jest sens mówić o nieuchwytności samej osoby jako kogoś, kto jest jeden i niepowtarzalny. Co prawda od czasu do czasu pojawiali się krytycy definicji Boecjusza, a przede wszystkim tacy myśliciele, którzy próbowali ją udoskonalać, ustalając dokładne określenia treści, czy wzbogacając ją o nowe treści. Dziś wśród najważniejszych treści pojęcia osoby wymienia się substancjalność, subsystencję, indywidualność 
(jednostkowość), rozumność, odniesienie (relację), nieudzielalność (incommunicabilitas), wolność i godność. Współcześnie jako najważniejsze wymienia się samoświadomość, podmiotowość, dialogiczność i zdolność do wejścia w relację jaty i do samooddania w miłości.

Teologowie - ale nie tylko - zawsze, aż po czasy współczesne, chętnie nawiązywali do definicji Boecjusza ${ }^{14}$. Powstaje pytanie, czy ze względu na jej merytoryczną trafność, czy też jedynie ze względu na przyzwyczajenie do tak skonstruowanego pojęcia? Ale to pozostawmy jedynie jako pytanie.

\section{Racje, dla jakich osoba wymyka się poznaniu?}

Gdy mówimy o racjach, dla których osoba jest niedefiniowalna, to wcale nie znaczy, że osoba sama w sobie jest w ogóle niepoznawalna.

Tu pragnę wskazać jedynie dwa powody, dla których osobę tak trudno zdefiniować, co więcej, dla których w ogóle nie można jej uczynić przedmiotem obiektywnego poznania, takiego jak w naukach przyrodniczych. Osoba jako rzeczywisty byt człowieka z natury swej ukrywa się przed oczami zewnętrznych obserwatorów. Jej istota - osoba sama w sobie - bezpośrednio dostępna jest wyłącznie jej samej, co ma miejsce w akcie intuicyjnej samoświadomości. I tylko tak. Ale to osobny temat do rozwinięcia.

Bernhard Welte wskazuje, że wszelkie próby zdefiniowania osoby natrafiają na niepokonalne trudności. Po pierwsze, dlatego że osoba niejako staje ponad definicją i przeciwstawia się jej, nie daje się zamknąć w ogólne pojęcia i podporządkować się im jako temu, co nadrzędne. Każda bowiem definicja odgranicza i zarazem ogranicza, zagarnia i podporządkowuje definiowany przedmiot ogólnym pojęciom rodzajowym i gatunkowym. Tymczasem: „Osoby nie można pochwycić i zagarnąć, znajduje się ona poza zasięgiem definicji, która chciałaby ją schwycić i, co najważniejsze, całkowicie jej się wymyka"15. Osoba jest zatem ponad gatunkiem, ponad rodzajem.

Po drugie - według Weltego - osoba nie jest przedmiotem pośród innych przedmiotów świata natury, przerasta świat natury. Dlatego:

Żadne określenie nie może w pełni wyrazić godności, która charakteryzuje człowieka w tym, co w nim najgębsze.(...) Samo Ja jest wolne i znajduje się poza wszelkimi możliwymi formami obiektywizacji, będąc źródłem, które należy wyłącznie do samego siebie i jako takie może zawsze swobodnie zgodzić się lub odmówić ${ }^{16}$.

14 Zob. W. Granat, Osoba. Próba definicji, Sandomierz 1961. Krytyczne uwagi na temat problematyki osoby w tradycyjnej filozofii zob. A. Rodziński, Osoba, moralność, kultura, Lublin 1989, s. 9-89.

15 B. Welte, Czas i tajemnica,Warszawa 2000, s. 45.

16 Ibidem, s. 45 i 46. 
Po trzecie, osoba wprawdzie istnieje w świecie materialnym, co więcej, jest włączona w procesy wewnątrzświatowe i podlega wpływom zewnętrznych wydarzeń, ale zarówno jej własna struktura, jej związki ze światem natury, jak i z innymi osobami wykraczają poza naturalny układ i porządek świata (zwłaszcza poza związki przyczyno-skutkowe). Welte:

To, co stanowi rdzeń i źródło Ja i Ty, nie da się nigdy sprowadzić do zewnętrznego powiązania o charakterze funkcjonalnym tak, jakby było przedmiotem. Jest to niemożliwe nie z powodu jakiejśs słabości, lecz z uwagi na swą ontologiczną rangę ${ }^{17}$.

$* * *$

Ze względu na tę ontologiczną rangę osoba jest nieporównywalna i niewymienialna z żadną inną osobą; ona sama stanowi punkt odniesienia. Welte:

Z uwagi na nieporównywalność początku, opartego jedynie na sobie samym, podstawowe kategorie osobowe: Ja, Ty My, nie mogą nigdy w sposób sensowny stać się pojęciami gatunkowymi. Osoba jako osoba nie stanowi nigdy poszczególnego przypadku tego, co ogólne. Jako osoba jest ona zawsze singulare tantum. Dlatego osób jako osób nie można także nigdy ze sobą sumować. Sumować można jedynie rzeczy tego samego rodzaju... ${ }^{18}$

Woły zaliczyć można do gatunku wołów, psy do gatunku psów, ale osoby nie możemy zaliczyć do gatunku osób; taki gatunek po prostu nie istnieje. Dlatego o osobie z pełnym uprawnieniem możemy powiedzieć, że jest jedna i jedyna, niepowtarzalna - hapax legomenon.

Osoba jest nie tylko niedefiniowalna ze względu na swoją jedyność, wyjątkowość i godność, ale w swym ukształtowaniu w ogóle jest nieuchwytna dla kogoś z zewnątrz. Istnieje bowiem sama-w-sobie-dla-siebie, jako monada, niedostępna dla oczu zewnętrznych obserwatorów. Poznawczo bezpośrednio dostępna jedynie sobie samej w aktach samoświadomości. Jako osoba jestem sobą w sobie, żyję w-sobie-dla-siebie jako skierowany do wewnątrz, co więcej, jako osoba istnieję tylko wewnątrz siebie „osłoniety” ciałem. W tym sensie jestem w ścisłym tego słowa znaczeniu bytem wewnętrznym; bytem skierowanym do wewnątrz i zamkniętym w sobie. Nikt nie może wtargnąć do mego wnętrza i ogarnąć mnie swoim spojrzeniem, zawładnąć mną i przywłaszczyć sobie; nawet gdy kogoś drugiego najserdeczniej zapraszam do siebie, gdy intensywnie pragnę być z nim i dla niego, zawsze ja pozostaję kimś radykalnie odrębnym, kimś tylko w-sobie-dla-siebie. I tam, wewnątrz samego siebie, jestem naprawdę sobą, w pełni mego ucieleśnienia. Ta wewnętrzność i zamknięcie w sobie

$17 \quad$ Ibidem, s. 49.

18 Ibidem, 52. 
w strukturze bytu osoby nie jest czymś przypadkowym; swój fundament ma w swej własnej naturze.

\section{Zatem: kto to jest osoba?}

Już samo pytanie brzmi trochę dziwnie. Myślę jednak, że można je postawić, choć odpowiedzieć na nie niezwykle trudno. Dlaczego? Bo brak adekwatnego języka i trafnych określeń. Osoba to człowiek, ale człowieka - o różnych kształtach i w wyglądzie - można zobaczyć, dotknąć. Osoby zaś dotknąć ani zobaczyć nie można; nie można więc powiedzieć, osoba tak oto wygląda. Ale osoba jest rzeczywistością, rzeczywistością ludzką, która zlewa się z człowiekiem w jedną całość ontyczną. I zobaczyć może ją - ale „zobaczyć” w zupełnie innym sensie - tylko ona samą siebie, gdy - w intuitywnym przeżywaniu aktów świadomości (samoświadomości) - bezpośrednio widzi bardzo wyraźnie, że to ona jest właśnie osobowym podmiotem tychże aktów, ich bytowym źródłem. Co więcej, że jako podmiot jest absolutnym i wyłącznym panem swego życia osobowego, jego prawowitym źródłem i ośrodkiem. Mówiąc o sobie „Ja myślę”, niczego sobie nie uzurpuję, nie wynoszę się egoistycznie ponad drugich ani nie mówię tak, bo mnie tak nauczono. Jako osoba - ów byt hapax legomenon jestem monadą odgraniczoną od wszystkiego, „zamkniętą” w-sobie-dla-siebie. Co prawda tak odgraniczony i zamknięty w sobie jest każdy żywy organizm, który jako całość wyodrębnia się od wszystkich innych organizmów. Ale być ja osobowym i widzieć swoje myślenie jako swoje najbardziej własne intymne życie to coś nieskończenie więcej niż być całością organiczną. Być osobą to właśnie być ową całością uwewnętrzniona, która żyje w sobie swoim własnym życiem: wszelkimi odczuciami i doznaniami cielesnymi, psychicznymi i duchowymi, swoimi myślami i aktami woli; mocą swego ciała i swego ducha. Jako osoba jestem sobą i wszystko jest moje, ja w całości przynależę do siebie wewnątrz samego siebie. To jest moja osobowa rzeczywistość.

Ja osobowe zatem to coś innego i coś znacznie więcej niż tylko centrum koordynacji procesów życiowych czy nawet psychicznych świata, w którym istniejemy ani wytwór myślenia; tym bardziej moje uwewnętrznione ja osobowe nie jest także żadnym wytworem procesów wewnątrzorganicznych; nie jest także żadną logiczną konstrukcją. Moje ja osobowe - ja jako podmiot świadomy siebie - dostępne mi w intuicji przeżywanych aktów świadomości - aktów emocjonalnych, aktów woli, postaw i decyzji - to samoistna egotyczność ściśle uwewnętrzniona. I w byciu człowieka owo uwewnętrznienie jest właśnie momentem konstytutywnym, bezwzględnie istotnym; momentem, który w bycie osoby musi być. Jako osobowy podmiot jestem właśnie tak ukonstytuowany, że jestem samościa, która może żyć swoim osobistym i intymnym życiem 
w-sobie-dla-siebie. Każdy inny żywy organizm żyje także jako całość, ale nie żyje swoim osobistym intymnym życiem w-sobie-dla-siebie, nie ma w sobie samej władzy powiedzenia Ja myśle, Ja wiem, Ja twierdzę, Ja czuję. Jedynie jako prawomocnie ukonstytuowana monada mam tę władzę. Żaden żywy organizm nie ma w ogóle w sobie władzy określenia się jako Ja. Żadne zwierzę nie odnajduje ani w sobie, ani w drugich żywych jestestwach - pies w drugim psie, kot w drugim kocie - owej monadycznej struktury, owego uwewnętrznionego bycia soba, które mogłoby być dla mnie Ty.

Ten konstytutywny moment w osobowej strukturze człowieka jest niezwykle trudno pojęciowo trafnie określić i znaleźć dla niego odpowiedni termin językowy. Ktoś może powiedzieć, że jest to właśnie dusza jako ośrodek koordynacji. Tak, ale taki ośrodek koordynacji jest także w innych żywych organizmach, stąd Arystoteles, który tak właśnie rozumiał duszę, że przyjmował istnienie duszy wegetatywnej, sensytywnej i umysłowej. Ale gdyby się nawet przyjęło, że chodzi tu o duszę duchową, groziłoby to swego rodzaju rozdwojeniem ontycznej i monadycznej jedności człowieka na dwa odrębne składniki: na „ciało” i na „duszę”. To zaś groziłoby popadnięciem w nieszczęsny dualizm ontologiczny. Tymczasem człowiek pierwotnie w całości swego bytu jest jeden, ukonstytuowany jest cały jako byt wewnątrz samego siebie w ja osobowe. Takie jest jego właściwe ucieleśnienie - jego entelecheia. To nie duchowa dusza w człowieku jest osobą, ale caly czlowiek jako cielesno-psychiczno-duchowa monada - jest osoba; czyli jest tym, kto-jest-soba-w-sobie źródłem aktów poznania i decyzji; kto jako podmiot żyje-w-sobie-dla-siebie, jakby „zwinięty” do wewnątrz i ukryty we własnym wnętrzu, jako podmiot zdolny do poznawania, do decyzji, do odczuwania, do komunikowania.

$Z$ braku lepszego wyrażenia ten tak istotnie ważny moment struktury człowieka jako osobowej monady określamy tutaj językowo złożonymi wyrażeniami opisowymi, stwierdzając, że osoba - jako monada - żyje-w-sobie-dla-siebie w ciele i w duszy. Można by nawet powiedzieć, że osoba swój własny byt - czy istotę własnego bytu - ukrywa w ciele jako w swojej własnej materii cielesnej. I być może tak jest w ciele innych bytów osobowych. Ale przed takim myśleniem znowu wzdrygamy się. Bo po Grekach odziedziczyliśmy negatywny pogląd na materię cielesną. Dlatego o ciele innych bytów (np. aniołów) ciągle myślimy po grecku; traktujemy cielesną materię ich bytu po platońsku czy po plotyńsku jako obciążenie, jako coś gorszego. Bo według Platona czy Plotyna - dusza sama w sobie jest prosta i niezmienna i jako taka doskonała, wieczna, ciało zaś jest tym, co „i śmiertelne, i bezmyślne, i wielopostaciowe, i rozkładalne”; tym, co „największe kajdany nakłada na duszę"19. Ponadto według Platona materialne

19 Platon, Fedon, XXVIII B i D (w przekł. W. Witwickiego), Warszawa 1968, s. 78 i 85. 
ciało było jedynie dodatkiem obciążającym duszę, jej „przyodziewkiem”. Choć Arystoteles ujmował te sprawy inaczej - widział bowiem w duszy formę substancjalna organizująca materię w ciało - to jednak i on również uważał duszę za Boski element w czlowieku ze względu na rozumność samej duszy, a nie na monadyczną strukturę jako właściwą entelecheję osobowego bytu człowieka.

Czy zatem można by powiedzieć, że osoba to człowiek uwewnętrzniony w całości swego bytu? Tak sądzę. Dlatego „szukanie rdzenia własnej samotności” jest jednocześnie własnym twórczym dziełem stawania się soba osoby jako podmiotu.

Słowa kluczowe: człowiek, ciało, psychika, dusza, duch, istota ludzka, ja osobowe, podmiotowość, samoświadomość.

\section{Bibliografia:}

1. Augustyn, O Trójcy Świętej, Kraków 1996.

2. Boecjusz, O pociechach filozofii ksiag pięcioro oraz traktaty teologiczne, thum. T. Jachimowski, Poznań 1927.

3. Granat W., Osoba. Próba definicji, Sandomierz 1961.

4. Guardini R., Koniec czasów nowożytnych - świat i osoba - wolność, taska, los, Kraków 1969.

5. Platon, Fedon, tłum. W. Witwicki, Warszawa 1968.

6. Rodziński A., Osoba, moralność, kultura, Lublin 1989.

7. Snell B., Odkrycie ducha. Studia o greckich korzeniach europejskiego myślenia, tłum. A. Onysymow, Warszawa 2009.

8. Welte B., Czas i tajemnica, Warszawa 2000. 